\title{
Exergy Analysis of an WGZ220/6.8-1 Type Alkali Recovery Boiler
}

\author{
Zaili Zhao \\ School of Energy and Power Engineering, Wuhan University of Technology, Wuhan 430063, China \\ Tel: 86-27-8674-7630 E-mail: zaili.zhao@mma.edu
}

\begin{abstract}
Zhaofeng Yuan
School of Energy and Power Engineering, Wuhan University of Technology, Wuhan 430063, China

E-mail: yzf_82@sina.com

Qinghua Cui

School of Energy and Power Engineering, Wuhan University of Technology, Wuhan 430063, China

E-mail: cuiqinghua848@sohu.com
\end{abstract}

$\mathrm{Na}$ Yan

Chemical Engineering Research Institute, Wuhan University of Technology, Wuhan 430063, China

E-mail: yanna198611@sohu.com

\begin{abstract}
The thermal performance of power generating and consuming devices can be improved significantly, both during design and operation. A solution can be sought by heat balance analyses fifty years ago. However, heat balance analysis neglects to recognize the irreversibility in processes and components. For the purpose of revealing fully losses and places which influence thermodynamic perfection of boiler, exergy analysis model of WGZ220/6.8-1 type alkali recovery boiler is established, exergy balance calculation software is designed by use of Microsoft Visual Basic 6.0, and the main factors which affect boiler system exergy loss are analyzed by using exergy balance method in this study. The discussions and results obtained may provide guidance for improving utilization of boiler energy.
\end{abstract}

Keywords: Alkali recovery boiler, Microsoft Visual Basic 6.0, Exergetic efficiency, Exergy analysis, Exergy loss

\section{Introduction}

Already fifty years ago, energy conversion systems were the target of a detailed analysis based on Second Law concepts. That analysis showed that the relevant design procedures of the time neglected to recognize that the irreversibility in processes and components depends on the energy 'degradation rate' and not only on the ratio between the intensities of the output and input flows, and that there is a scale of energy quality that can be quantified by an entropy analysis. In essence, the legacy of this approach, universally accepted today, is that the idea of 'conversion efficiency' based solely on First Law considerations is erroneous and misleading. This method evolved throughout the years into the so-called 'availability analysis', later properly renamed 'exergy analysis' found impact on the energy conversion system community, and it has had a very profound impact on the energy conversion system community.( Ahern J.,1980)

Heat balance analysis which is based on the first law of thermodynamics is the primary method to analyze energy use characteristics of boiler unit. This method is used to analyze situation of energy use and evaluate integrity of systems or equipments according to the conservation of energy principle, which may be expressed as follows: The net change (increase or decrease) in the total energy of the system during a process is equal to the difference between the total energy entering and the total energy leaving the system during that process. (Tong, J G, Huang, X H, and Yang, Q S, 1995, 5:p. 33-35)

In order to fully measure the degree of perfection of boiler energy use, exergy analysis method is worthy of our 
consideration, because it is not enough to calculate boiler energy use by heat balance analysis method only. (Zhao, X F and Shang, F M,2008, 9(2): p.32-33) The essence of exergy analysis is a combination of the First and Second Law of thermodynamics, that is, conversion, transmission, use and loss of exergy (available energy) in systems or equipments are analyzed and revealed by considering quantity and quality of energy together, thus exergy analysis is also known as the Second Law analysis by many researchers, it is concerned with the degradation of energy during a process, the entropy generation, and the lost opportunities to do work, so it offers plenty of room for improvement. Exergy balance calculation is the main calculation method of systems or equipments, so it is also known as exergy balance method, and exergetic efficiency is the main thermodynamic index.(Wu, C Z, Zhang, S Z and Sun Z J, 2000,p.46-50)

This paper deals with the problem of energy conversion in boiler with exergy analysis method. There are no systematic research results about this problem at present, although boiler is designed and operated with high thermal efficiency, plenty of available energy is not taken into account and wasted. For example, thermal efficiency of $\mathrm{HG}-75 / 3.82-7$ type boiler in China is about $80 \%$, its working condition seems to be very well, and however, exergetic efficiency of this boiler calculated by researcher is only $38 \%$, which means most of energy is wasted. WGZ220/6.8-1 type alkali recovery boiler is chosen as an object of study due to its advantages compared with other kinds of boilers. (Zhao, X F and Shang, F M,2008, 9(2): p.32-33)

The alkali recovery, which represents an important economic and ecological factor, includes the processes of black-liquor evaporation, combustion, green-liquid causticizing and alkali recovery. Alkali recovery Boiler is the main equipment for recovering valuable caustic soda - NaOH. (Wang Z M, Xiao J S , Zhang L, Zhao Z L and Zhang X J. 2007(8):p.143 ) Therefore exergy analysis is quite important for the water tubes panel of evaporators in the boiler. With the constant development of the human civilization, the modern social demand for paper is becoming larger and larger. Black liquid produced by paper mill, if not to be dealt with and discharged at will, certainly will cause serious pollution to the rivers and lakes. And alkali recovery boiler dealing with the black liquid can not only fully recover the alkaline in the black liquid, but also utilize burning of the organic matter in black liquid in order to produce the industrial steam and get benefit two times. Therefore it is great beneficial to improve the economic benefits of the papermaking course and the essential equipment of pollution-controlled of paper mill, so WGZ220/6.8-1 type alkali recovery boiler is taken as subject of study, analysis is carried out on basis of producer's design data.

The boiler is a single drum, natural circulation, low odor type alkali recovery boiler. With whole steel, full suspension and full-sealed structure, gravity of boiler is withstood by roof through a boom. The principle of alkali recovery boiler is that waste water (commonly known as black liquor) which is discharged after making paper is concentrated as fuel, which is put into boiler for combustion. Then liquid slag which is the burning resultant of black liquor is discharged from the bottom and recovered into alkali after a causticizing process. Alkali recovery boilers are used by paper mills for not only recovering alkali caused by making paper but also generate heat and electricity. Consequently, the purposes of recycling, energy conservation and reducing pollution are achieved. Alkali recovery boiler was originally designed to deal with waste water generated by pulp and recycle cooking alkali, but there are three effects for current alkali recovery boiler: in order to generate steam by burning organic matter in black liquor; generation of a green solution for causticizing, reduction of pollutant emission, energy-saving and environmental protection. Purposes above will be achieved with exergy analysis of this boiler. Boiler design parameters, thermal properties and the fuel element analysis are shown in table 1 ..

\section{Exergy analysis model of boiler}

Boiler is taken as a whole body in this paper due to its complicated structure, and boiler situation of energy use is analyzed by exergy balance method as shown in figure $1 . . E_{1}$ is external exergy loss taken away by exhaust gas, $E_{2}$ is external exergy loss taken away by superheated steam, $E_{3}$ is external exergy loss caused by heat elimination, $E_{4}$ is the sum of other exergy losses, $E_{5}$ is exergy brought by feed water, $E_{6}$ is exergy brought by fuel, and $E_{7}$ is exergy brought by fresh air.(Maques J C, Pardal M A and Nielsen S N, et al,1997,p. 155-157).

Exergy balance equation of boiler is

$\mathrm{E}_{1}+\mathrm{E}_{2}+\mathrm{E}_{3}+\mathrm{E}_{4}=\mathrm{E}_{5}+\mathrm{E}_{6}+\mathrm{E}_{7}$,

i.e.,

$\mathrm{m}_{1} \mathrm{e}_{1}+\mathrm{m}_{2} \mathrm{e}_{2}+\mathrm{m}_{3} \mathrm{e}_{3}+\mathrm{m}_{4} \mathrm{e}_{4}=\mathrm{m}_{5} \mathrm{e}_{5}+\mathrm{m}_{6} \mathrm{e}_{6}+\mathrm{m}_{7} \mathrm{e}_{7}$,

where $e_{i}[\mathrm{~kJ} / \mathrm{kg}](\mathrm{i}=1 \sim 7)$ is specific exergy. Equation (2) can be changed into the following equation because $\mathrm{m}_{2}$ is equal to $\mathrm{m}_{5}$ :

$m_{1} e_{1}+m_{2}\left(e_{2}-e_{5}\right)+m_{3} e_{3}+m_{4} e_{4}=m_{6} e_{6}+m_{7} e_{7}$.

2.1 Exergy of liquid fuel(Yao, S G,2003,p.125-126)

Chemical exergy of liquid fuel is defined as follows: 
$\mathrm{e}_{\mathrm{ch}}=\mathrm{Q}_{1}\left(1.0038+0.1365 \frac{\mathrm{H}}{\mathrm{C}}+0.0308 \frac{\mathrm{O}}{\mathrm{C}}+0.0104 \frac{\mathrm{S}}{\mathrm{C}}\right)[\mathrm{kJ} / \mathrm{kg}(\mathrm{F})]$

where $\mathrm{H}, \mathrm{O}, \mathrm{C}$ and $\mathrm{C}$ are Mass percentage of hydrogen, carbon, oxygen and sulfur respectively existing in liquid fuel, and $\mathrm{Q}_{1}[\mathrm{~kJ} / \mathrm{kg}(\mathrm{F})]$ is low heat value of fuel. Physical exergy of liquid fuel is defined as follows:

$\mathrm{e}_{\mathrm{ph}}=\mathrm{c}_{\mathrm{f}}\left[\left(\mathrm{T}-\mathrm{T}_{0}\right)-\mathrm{T}_{0} \ln \frac{\mathrm{T}}{\mathrm{T}_{0}}\right][\mathrm{kJ} / \mathrm{kg}(\mathrm{F})]$,

where $T[K]$ is thermodynamic temperature of liquid fuel, $T_{0}[K]$ is environmental temperature and $c_{f}[\mathrm{~kJ} / \mathrm{kg} \cdot \mathrm{K}]$ is average specific heat of liquid fuel, which can be obtained by formula as follows:

$\mathrm{c}_{\mathrm{f}}=1.7375+0.002512 \mathrm{t}[\mathrm{kJ} / \mathrm{kg} \cdot \mathrm{K}]$,

where $t\left[{ }^{\circ} \mathrm{C}\right]$ is temperature of liquid fuel.

Thus, exergy of liquid fuel is obtained as follows:

$\mathrm{e}_{6}=\mathrm{e}_{\mathrm{ch}}+\mathrm{e}_{\mathrm{ph}}[\mathrm{kJ} / \mathrm{kg}(\mathrm{F})]$,

\subsection{Exergy loss of the combustion process}

There is no heat loss in the adiabatic combustion process, so gas exergy is equal to sum of fuel and fresh air exergy before combustion theoretically. However, there is irreversible loss in actual process of combustion, so gas exergy is smaller than that actually.(Yunus A. Cengel and Michael A,2002,p.110).

Adiabatic combustion temperature is the maximum temperature which combustion gas can reach in an adiabatic combustion process. The expression of heat balance equation of combustion process is defined as follows:

$$
\mathrm{V}_{\mathrm{gc}}^{\prime} \mathrm{p}_{\mathrm{m}}^{\prime}\left(\mathrm{T}_{\mathrm{ad}}-\mathrm{T}_{0}\right)=\mathrm{Q}_{1} \text {, }
$$

so, adiabatic combustion temperature can be obtained as follows:

$\mathrm{T}_{\mathrm{ad}}=\mathrm{T}_{0}+\frac{\mathrm{Q}_{1}}{\mathrm{~V}_{\mathrm{g}} \mathrm{c}_{\mathrm{p}, \mathrm{m}}^{\prime}}[\mathrm{K}]$.

Gas exergy is defined as follows:

$\mathrm{e}_{\mathrm{ad}}=\mathrm{V}_{\mathrm{gc}} \mathrm{p}, \mathrm{m}^{\prime}\left(\mathrm{T}_{\mathrm{ad}}-\mathrm{T}_{0}\right)\left(1-\frac{\mathrm{T}_{0}}{\mathrm{~T}_{\mathrm{ad}}-\mathrm{T}_{0}} \ln \frac{\mathrm{T}_{\mathrm{ad}}}{\mathrm{T}_{0}}\right)=\mathrm{Q}_{1}\left(1-\frac{\mathrm{T}_{0}}{\mathrm{~T}_{\mathrm{ad}}-\mathrm{T}_{0}} \ln \frac{\mathrm{T}_{\mathrm{ad}}}{\mathrm{T}_{0}}\right)[\mathrm{kJ} / \mathrm{kg}(\mathrm{F})]$,

where $\mathrm{V}_{\mathrm{g}}\left[\mathrm{Nm}^{3} / \mathrm{kg}(\mathrm{F})\right]$ is actual flue gas volume and $\mathrm{c}_{\mathrm{p}, \mathrm{m}}$ is average specific heat capacity of fuel gas at constant pressure, which is $1.549\left[\mathrm{~kJ} /\left(\mathrm{Nm}^{3} \cdot \mathrm{K}\right)\right]$ in this paper.

Fresh air exergy is defined as follows:

$\mathrm{e}_{7}=\mathrm{m}_{7}\left[\left(\mathrm{~h}_{7}-\mathrm{h}_{07}\right)-\mathrm{T}_{0}\left(\mathrm{~S}_{7}-\mathrm{S}_{07}\right)\right][\mathrm{kJ} / \mathrm{kg}(\mathrm{F})]$,

where $h_{7}[\mathrm{~kJ} / \mathrm{kg}]$ is fresh air specific enthalpy, $h_{07}[\mathrm{~kJ} / \mathrm{kg}]$ is fresh air specific enthalpy in environmental state, $\mathrm{s}_{7}$ $[\mathrm{kJ} / \mathrm{kg} \cdot \mathrm{K}]$ is fresh air specific entropy, $\mathrm{s}_{07}[\mathrm{~kJ} / \mathrm{kg} \cdot \mathrm{K}]$ is fresh air specific entropy in environmental state and $\mathrm{m}_{7}[\mathrm{~kg}]$ is mass of fresh air which is supplied for combustion of per kilogram fuel in boiler.

Thus fuel exergy can be obtained as follows:

$\mathrm{e}_{\mathrm{f}}=\mathrm{e}_{6}+\mathrm{e}_{7}[\mathrm{~kJ} / \mathrm{kg}(\mathrm{F})]$.

Exergy loss during combustion is

$\mathrm{e}_{1, \mathrm{c}}=\mathrm{e}_{\mathrm{f}}-\mathrm{e}_{\mathrm{ad}}=\mathrm{T}_{0} \Delta \mathrm{s}+\mathrm{Q}_{1} \frac{\mathrm{T}_{0}}{\mathrm{~T}_{\mathrm{ad}}-\mathrm{T}_{0}} \ln \frac{\mathrm{T}_{\mathrm{ad}}}{\mathrm{T}_{0}}[\mathrm{~kJ} / \mathrm{kg}(\mathrm{F})]$,

where $\Delta \mathrm{s}[\mathrm{kJ} / \mathrm{kg} \cdot \mathrm{K}]$ is entropy difference of resultant and reactant.

\subsection{Exergy of feed water and superheated steam}

Feed water specific exergy is defined as follows:

$\mathrm{e}_{5}=\left(\mathrm{h}_{5}-\mathrm{h}_{05}\right)-\mathrm{T}_{0}\left(\mathrm{~s}_{5}-\mathrm{S}_{0}\right)[\mathrm{kJ} / \mathrm{kg}]$,

where $h_{5}[\mathrm{~kJ} / \mathrm{kg}]$ is feed water specific enthalpy, $\mathrm{h}_{05}[\mathrm{~kJ} / \mathrm{kg}]$ is feed water specific enthalpy in environmental state, $\mathrm{s}_{5}$ $[\mathrm{kJ} / \mathrm{kg} \cdot \mathrm{K}]$ is feed water specific entropy and $\mathrm{s}_{05}[\mathrm{~kJ} / \mathrm{kg} \cdot \mathrm{K}]$ is feed water specific entropy in environmental state.

Superheated steam specific exergy is defined as follows: 


$$
\mathrm{e}_{2}=\left(\mathrm{h}_{2}-\mathrm{h}_{02}\right)-\mathrm{T}_{0}\left(\mathrm{~S}_{2}-\mathrm{S}_{02}\right)[\mathrm{kJ} / \mathrm{kg}] \text {, }
$$

where $h_{2}[\mathrm{~kJ} / \mathrm{kg}]$ is superheated steam specific enthalpy, $\mathrm{h}_{02}[\mathrm{~kJ} / \mathrm{kg}]$ is superheated steam specific enthalpy in environmental state, $s_{2}[\mathrm{~kJ} / \mathrm{kg} \cdot \mathrm{K}]$ is superheated steam specific entropy and $\mathrm{s}_{02}[\mathrm{~kJ} / \mathrm{kg} \cdot \mathrm{K}]$ is superheated steam specific entropy in environmental state.

\subsection{Exergetic efficiency of boiler}

Exergetic efficiency of combustion is

$$
\eta_{\mathrm{e}, \mathrm{c}}=\frac{\mathrm{e}_{\mathrm{f}}-\mathrm{e}_{1, \mathrm{c}}}{\mathrm{e}_{\mathrm{f}}}=1-\frac{\mathrm{e}_{1, \mathrm{c}}}{\mathrm{e}_{\mathrm{f}}} .
$$

Exergetic efficiency of heat transfer is

$$
\eta_{\mathrm{e}, \mathrm{h}}=\frac{\mathrm{m}_{2}\left(\mathrm{e}_{2}-\mathrm{e}_{5}\right)}{\mathrm{e}_{\mathrm{f}-\mathrm{e}_{1, \mathrm{c}}}},
$$

where $\mathrm{m}_{2}[\mathrm{~kg}]$ is steam mass which is produced by burning per kilogram fuel in boiler.

Thermal efficiency of heat transfer reveals only extent of boiler exhaust and heat transfer loss, while exergetic efficiency of heat transfer can disclose irreversible loss which is produced by heat transfer, which is caused by a limited temperature differences from fuel gas to water and steam.(Jin, Y L,1997, 6(1):p. 6-9)

The exact expression of exergetic efficiency of boiler is that how much exergy which is produced by burning fuel completely within an hour can be used to improve feed water and steam exergy. Exergetic efficiency of boiler is the product of exergetic efficiency of combustion and exergetic efficiency of heat transfer, so it can be expressed as follows:

$$
\eta_{e, B}=\eta_{e, c} \eta_{e, h} \text {. }
$$

\section{Exergy balance calculation software}

Environmental temperature and atmospheric pressure are established as $293.15 \mathrm{~K}$ and $0.1 \mathrm{MPa}$ respectively in programming. According to formula above the data input window are obtained by use of Microsoft Visual Basic 6.0 as shown in figure 2.. After all parameters are input into data input window and button of calculation is clicked, calculation results output window will show all required results as shown in figure 3. . Parameters in data input window such as calorific value, Temperature of black liquor, and so on are directly from table1. But there are some deficiencies, that is, some parameters can not be input directly into window, for instance, there is no exact number of actual fuel gas volume because of difference of units, unit of $\mathrm{v}_{\mathrm{g}}$ in boiler specification table is $\mathrm{Nm}^{3} / \mathrm{h}$, but it was established as $\mathrm{Nm} / \mathrm{kg}(\mathrm{F})$ in programming, so a simple calculation is essential. Moreover, specific entropy of various working mediums can not be obtained directly from boiler specification table.

This software is a general calculating software of exergy analysis of boiler. It is very convenient for researchers to calculate exergy analysis results of other boilers by using this software. For example, when all required designed parameters are obtained from producers, researchers just need to input relevant parameters into data input window, all calculated results will shown in calculation results output window, thus analysis can be made by considering these parameters of results.

\section{Calculating results and analysis}

According to calculation results above, table 2. is obtained.

According to table 1., thermal efficiency of boiler is $75 \%$, while exergetic efficiency of boiler is $45.49 \%$ according to results in table 2.. So exergetic efficiency is far bellower than thermal efficiency. There are two main reasons as follows:

(1) Exergetic efficiency of combustion is low

Fuel combustion is a strongly irreversible process. Although chemical energy is converted into heat energy in combustion process, and quantity of energy is constant in conversion and transfer process, exergy is reduced greatly. According to formula (12), exergy loss in combustion process will increase due to increment of difference of resultant and reactant $\Delta \mathrm{s}$. When adiabatic combustion temperature $\mathrm{T}_{\mathrm{ad}}$ increases, exergy loss will reduce, however, actual volume of flue gas can not be closed to ideal one so as that adiabatic combustion temperature $\mathrm{T}_{\mathrm{ad}}$ is not high enough, about $1228.39{ }^{\circ} \mathrm{C}$ or so, consequently Exergetic efficiency of combustion is too low, only about 57.29\%.(Xiang, X Y,1990,p.201-202).

In previous study of alkali recovery boiler, thermal balance analysis is the primary method, so the design of boiler aims at improvement of thermal efficiency. Normally, exhaust temperature is risen by $12-15 \%$, exhaust heat loss will rise by about 1\%,( Ma J H and Wang S Q. 2001(1):p.30) thus exhaust temperature will be limited to a state as low as possible in order to only increase thermal efficiency. However, according to analysis above, adiabatic combustion temperature 
$\mathrm{T}_{\mathrm{ad}}$ should be raised which leads to low exergy loss. Exergy analysis shoud be done under the premise of without affecting thermal efficiency of the boiler, there must be a most optimizing value in calculation of thermal and erexgy balance. So boiler should not be designed and operated by simply increase or decrease exhaust temperature, comprehensive consideration should be taken into account.

(2) Exergetic efficiency of heat transfer is low

Temperature difference is the driving force of heat transfer. It is a typical irreversible phenomenon that heat is transferred due to limited temperature difference, thus there is exergy loss existing in this process. Exergy loss of heat transfer is related to temperature difference. The greater temperature difference, the greater exergy loss; On the contrary, the smaller temperature difference, the smaller exergy loss. Adiabatic combustion temperature of flue gas $\mathrm{T}_{\mathrm{ad}}$ $\left(1228.39^{\circ} \mathrm{C}\right)$ is much larger than rated steam temperature $\left(480^{\circ} \mathrm{C}\right)$, consequently Exergetic efficiency of heat transfer is too low, only about $79.41 \%$.

After establishing adiabatic combustion temperature of flue gas $\mathrm{T}_{\mathrm{ad}}$ according to above discussion, rated steam temperature should be increased as high as possible by many methods such as change material of heat transfer surface and maintain cleaning of heat transfer surface in daily operation to achieve better heat transfer.

\section{Conclusions}

(1) Exergetic efficiency of boiler is made up of product of exergetic efficiency of combustion and heat transfer. Basic reasons which affect exergetic efficiency are adiabatic combustion temperature, difference of resultant and reactant and temperature difference of heat transfer.

(2) Exergy losses of boiler include exergy loss of combustion, exergy loss of heat transfer and other exergy losses. Exergy loss caused by irreversible combustion occupies a large proportion.

(3) Boiler parameters should be changed for optimizing exergetic efficiency under the premise of without affecting thermal efficiency of the boiler when it is designed, so exergetic efficiency can reach maximum, and finally, purpose of energy saving will be achieved.

(4) In order to achieve the best exergetic efficiency, the boiler should be operated in accordance with rated working condition strictly. In condition of ensuring a good mix of fuel and fresh air, excess air coefficient should be decreased for WGZ220/6.8-1 type alkali recovery boiler. Implementing device can be used to adjust to the amount of combustion air supply, thus the best combustion condition can be obtained.

\section{References}

Ahern J. (1980). The exergy method of Energy Systemsanalysis, Wiley, New York.

Jin, Y L. (1997). Exergy analysis of heat exchanger. J. Huaiyin Inst. Tech. (soc. Sci. Edi.). 1997, 6(1):p. 6-9.

Ma J H and Wang S Q. (2001). Discussion on How to Improve the Circulating Efficiency of Alkali Recovery Boiler System. ENERGY TECHNOLOGY. 2001(1):p.30.

Maques J C, Pardal M A and Nielsen S N, et al. (1997). Analysis of theproperties of exergy and biodiversity along an estuarine gradient of eutrophication. Ecol Model. 1997, p. 155-157.

Tong, J G, Huang, X H, and Yang, Q S. (1995). Exergy analysis of steam power plant of warship. Ship Engineering: 1995, 5:p. 33-35.

Wang Z M, Xiao J S , Zhang L, Zhao Z L and Zhang X J. (2007). Heat Transfer and Thermal Stress Analysis of Heated Tube Sheets in an Alkalinity Recycling Boiler. JOURNAL OF WUHAN UNIVERSITY OF TECHNOLOG $Y .2007(8):$ : 143 .

Wu, C Z, Zhang, S Z and Sun Z J. (2000). Exergy analysis basis of thermal process. Zhejiang: Zhejiang University Press, 2000, p. 46-50.

Xiang, X Y. (1990). Engineering Exergy Analysis. Beijing: Oil Industry Press, 1990, p. 201-202.

Yao, S G. (2003). Analysis of marine thermodynamic system. Beijing: Science Press, 2003, p. 125-126.

Yunus A. Cengel and Michael A. Boles. (2002). Thermodynamics. Beijing: Tsinghua University Press.2002, p. 110.

Zhao, X F and Shang, F M. (2008). Thermal balance test and energy analysis of HG - $75 / 3.82-7$ type of boiler. $J$. Changchun Inst. Tech. (Nat. Sci. Edi.). 2008, 9(2): p.32-33. 
Table 1. Boiler specification

\begin{tabular}{|c|c|c|}
\hline \multicolumn{3}{|c|}{ Boiler design parameters } \\
\hline Weight of black liquor processed per day & {$[\mathrm{tds} / \mathrm{d}]$} & 1050 \\
\hline Rated evaporation & {$[\mathrm{t} / \mathrm{h}]$} & 220 \\
\hline Rated Steam Pressure & {$[\mathrm{MPa}]$} & 6.8 \\
\hline Rated Steam Temperature & {$\left[{ }^{\circ} \mathrm{C}\right]$} & 480 \\
\hline Feed water temperature & {$\left[{ }^{\circ} \mathrm{C}\right]$} & 130 \\
\hline Gas temperature in outlet of economizer & {$\left[{ }^{\circ} \mathrm{C}\right]$} & 170 \\
\hline Average air temperature & {$\left[{ }^{\circ} \mathrm{C}\right]$} & 138 \\
\hline Average air pressure & {$[\mathrm{Mpa}]$} & $2.4 \times 10^{-3}$ \\
\hline Theoretical total air volume & {$\left[\mathrm{Nm}^{3} / \mathrm{h}\right]$} & $215 \times 10^{3}$ \\
\hline Gas volume in funnel & {$\left[\mathrm{Nm}^{3} / \mathrm{h}\right]$} & $315 \times 10^{3}$ \\
\hline \multicolumn{3}{|c|}{ Boiler thermal properties } \\
\hline Exhaust gas loss & {$[\%]$} & 8.26 \\
\hline Chemical incomplete combustion loss & {$[\%]$} & 0.5 \\
\hline Mechanical incomplete combustion loss & {$[\%]$} & 0.5 \\
\hline Heat loss & {$[\%]$} & 1.0 \\
\hline Ash physical heat loss & {$[\%]$} & 14.74 \\
\hline Thermal efficiency & {$[\%]$} & 75 \\
\hline Furnace volumetric heat load & {$\left[\mathrm{kW} / \mathrm{m}^{3}\right]$} & 121.84 \\
\hline Furnace section heat load & {$\left[\mathrm{MW} / \mathrm{m}^{2}\right]$} & 3.19 \\
\hline Furnace bottom load & {$\left[\mathrm{tds} / \mathrm{d} \cdot \mathrm{m}^{2}\right]$} & 16.42 \\
\hline \multicolumn{3}{|c|}{ Fuel element analysis (Black liquor) } \\
\hline $\mathrm{C}$ & {$[\%]$} & 36 \\
\hline $\mathrm{H}$ & {$[\%]$} & 3.6 \\
\hline $\mathrm{O}$ & {$[\%]$} & 37 \\
\hline $\mathrm{S}$ & {$[\%]$} & 2.9 \\
\hline $\mathrm{Si}$ & {$[\%]$} & 0.6 \\
\hline $\mathrm{Na}$ & {$[\%]$} & 17.8 \\
\hline $\mathrm{N}$ & {$[\%]$} & 0.2 \\
\hline $\mathrm{K}$ & {$[\%]$} & 1.0 \\
\hline $\mathrm{Cl}$ & {$[\%]$} & 0.7 \\
\hline Other & {$[\%]$} & 0.2 \\
\hline Sum & {$[\%]$} & 100 \\
\hline Calorific value & {$[\mathrm{MJ} / \mathrm{kg}]$} & 13.7 \\
\hline Temperature of black liquor & {$\left[{ }^{\circ} \mathrm{C}\right]$} & 110 \\
\hline
\end{tabular}


Table 2. Calculating results of exergy analysis

\begin{tabular}{|c|c|c|c|}
\hline \multicolumn{2}{|c|}{ Names } & Results \\
\hline Exergy of liquid fuel & $\mathrm{e}_{6}$ & {$[\mathrm{~kJ} / \mathrm{kg}(\mathrm{F})]$} & 14407.41 \\
Adiabatic combustion temperature & $\mathrm{T}_{\mathrm{ad}}$ & {$[\mathrm{K}]$} & 1521.54 \\
Fresh air exergy & $\mathrm{e}_{7}$ & {$[\mathrm{~kJ} / \mathrm{kg}(\mathrm{F})]$} & 107.89 \\
Fuel exergy & $\mathrm{e}_{\mathrm{f}}$ & {$[\mathrm{kJ} / \mathrm{kg}(\mathrm{F})]$} & 14515.30 \\
Gas exergy & $\mathrm{e}_{\mathrm{ad}}$ & {$[\mathrm{kJ} / \mathrm{kg}(\mathrm{F})]$} & 8315.90 \\
Exergy loss of combustion & $\mathrm{e}_{1, \mathrm{c}}$ & {$[\mathrm{kJ} / \mathrm{kg}(\mathrm{F})]$} & 6199.40 \\
Feed water exergy & $\mathrm{m}_{2} \mathrm{e}_{5}$ & {$[\mathrm{~kJ} / \mathrm{kg}(\mathrm{F})]$} & 387.21 \\
Superheated steam exergy & $\mathrm{m}_{2} \mathrm{e}_{2}$ & {$[\mathrm{~kJ} / \mathrm{kg}(\mathrm{F})]$} & 6991.09 \\
Exergetic efficiency of combustion & $\eta_{\mathrm{e}, \mathrm{c}}$ & {$[\%]$} & 57.29 \\
Exergetic efficiency of heat transfer & $\eta_{\mathrm{e}, \mathrm{h}}$ & {$[\%]$} & 79.41 \\
Exergetic efficiency of boiler & $\eta_{\mathrm{e}, \mathrm{B}}$ & {$[\%]$} & 45.49 \\
Exergy loss coefficient of boiler & $\xi_{\mathrm{e}, \mathrm{B}}$ & {$[\%]$} & 54.51 \\
\hline
\end{tabular}

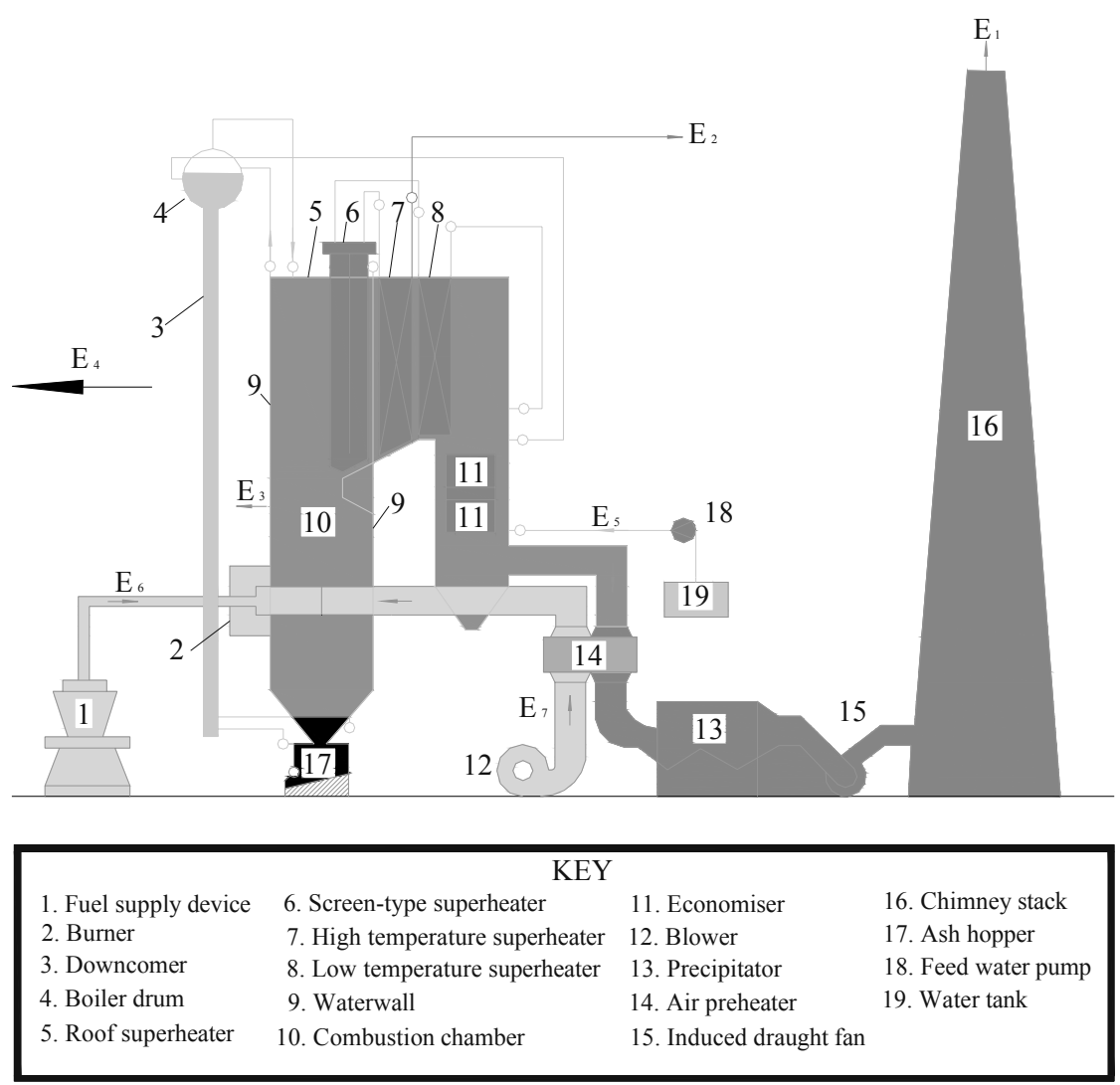

Figure 1. Exergy analysis model of boiler 


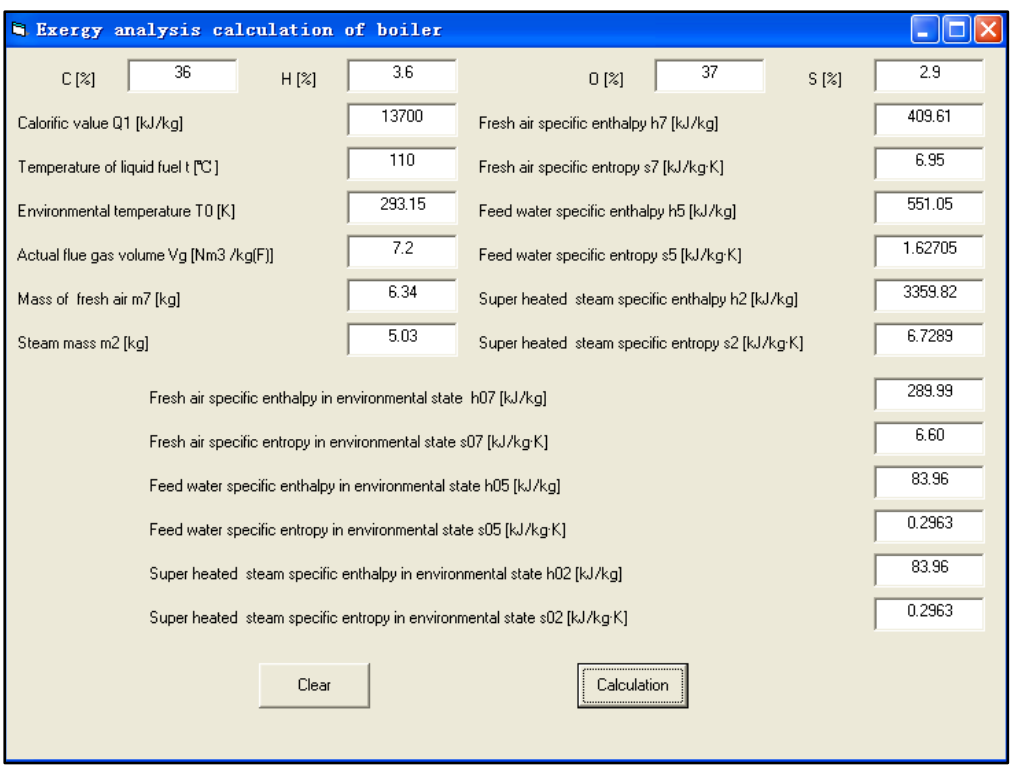

Figure 2. Data input window

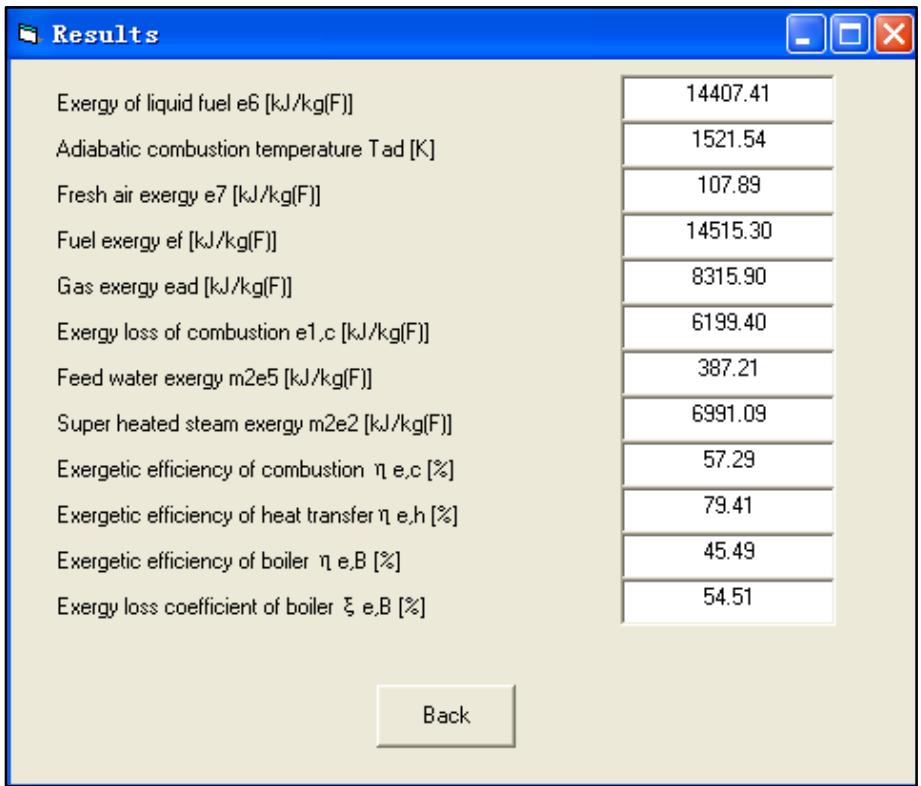

Figure 3. Calculation results output window 